\title{
Pegmatite dykes and quartz veins with tourmaline: an example of partial melting in the contact aureole of the Chandman Massif intrusion, SW Mongolia
}

\author{
David BURIÁNEK*, Pavel HANŽL, Kristýna HRDLIČKOVÁ \\ Czech Geological Survey, Leitnerova 22,65859 Brno, Czech Republic; david.burianek@geology.cz \\ * Corresponding author
}

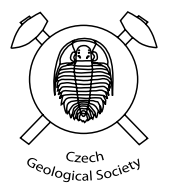

Pegmatite dykes with tourmaline and quartz-tourmaline veins in the Chandman Khayrkhan Crystalline Complex (the Eastern Mongolian Altay range, SW Mongolia) are spatially related to the contact aureole of the Variscan granitoids of the Chandman Massif. Tourmalines are also present in pegmatites that intruded into the I-type granitoids of the Chandman Massif near the contact with surrounding migmatites. The fluid-present melting of metapelites in wall rocks of the I-type granodiorites and tonalities can be considered as the main process inducing the boron-rich granitic melt formation. Variations in chemical compositions of tourmaline from several pegmatite dykes, mainly in $\mathrm{Na}, \mathrm{Ca}, \mathrm{Al}, \mathrm{Fe}$ and $\mathrm{Mg}$, are interpreted as a result of fractionation of the parental melt. The quartz-tourmaline veins represent a product of crystallization of aqueous fluid exsolved from the pegmatite melt. Chemical compositions of tourmaline with elevated $\mathrm{Ca}$ and $\mathrm{Mg}$ are interpreted to reflect mixing of the boron-rich postmagmatic fluids with $\mathrm{Mg}-\mathrm{Ca}$ enriched external component represented by fluids from the biotite-rich metaluminous igneous host rocks.

Keywords: tourmaline, pegmatite, microchemistry, compositional evolution, Mongolian Altay Mts., SW Mongolia Received: 11 February 2010; accepted: 28 April 2011; handling editor: M. Novák

\section{Introduction}

Partial melting in the wall-rock complexes usually follows intrusions of large I-type granitoid plutons (e.g. Montel et al. 1992; Finger and Clemens 1995). Formation and segregation of melt in the anatectic zone distinctively depend on the presence or absence of volatile components (Harris et al. 2003). Boron is one of the most important volatile components that reduces the solidus temperature and viscosity of melts (Pichavant 1981; Dingwell et al. 1992; Baker and Vaillancourt 1995). Boron behaves as an incompatible element for majority of rock-forming minerals except for tourmaline, which is stable up to upper amphibolitefacies conditions (Sperlich et al. 1996). Tourmaline breaks down during the metamorphic reaction consuming biotite (Kawakami 2001). Boron-bearing peraluminous granitic melt crystallizes under significantly lower temperature then boron-poor granitoids (Pichavant 1981) and may form granite and pegmatite dykes in the cooling granodiorite plutons. In course of the peraluminous melt evolution, tourmaline may grow from the early magmatic (London et al. 1996) to early subsolidus stage as well as under hydrothermal conditions (London and Manning 1995; Buriánek and Novák 2004). Its composition depends on the origin and evolution of the parental magma and/or fluid phases (Henry and Guidotti 1985; London and Manning 1995).
The pegmatite dykes and quartz veins spatially related to the Chandman Massif in the eastern part of the Mongolian Altay range (the Chandman district of GobiAltay Aymag, SW Mongolia) provide a good example for the study of changes in tourmaline composition during evolution of small amount of melt from its early crystallization to the post-magmatic hydrothermal fluids separation stage.

\section{Geological setting}

Southwestern part of Mongolia consists of number of tectonic domains, which belong to the Altaid Tectonic Collage (Sengör et al. 1993). The Chandman Massif is situated at the northern margin of the Gobi-Altay Terrane, near the boundary with the Lake Terrane (Economos et al. 2008). The Gobi-Altay Terrane is composed of the volcano-sedimentary sequences of forearc/backarc character and the Lake Terrane exhibits island-arc features (Badarch et al. 2002). The Chandman Massif (Fig. 1) intruded into the Chandman Khayrkhan Crystalline Complex and into the northern part of the Tugrug Formation. The Quaternary sediments cover western and eastern boundaries of the Chandman Massif (Hanžl and Aichler eds 2007). 


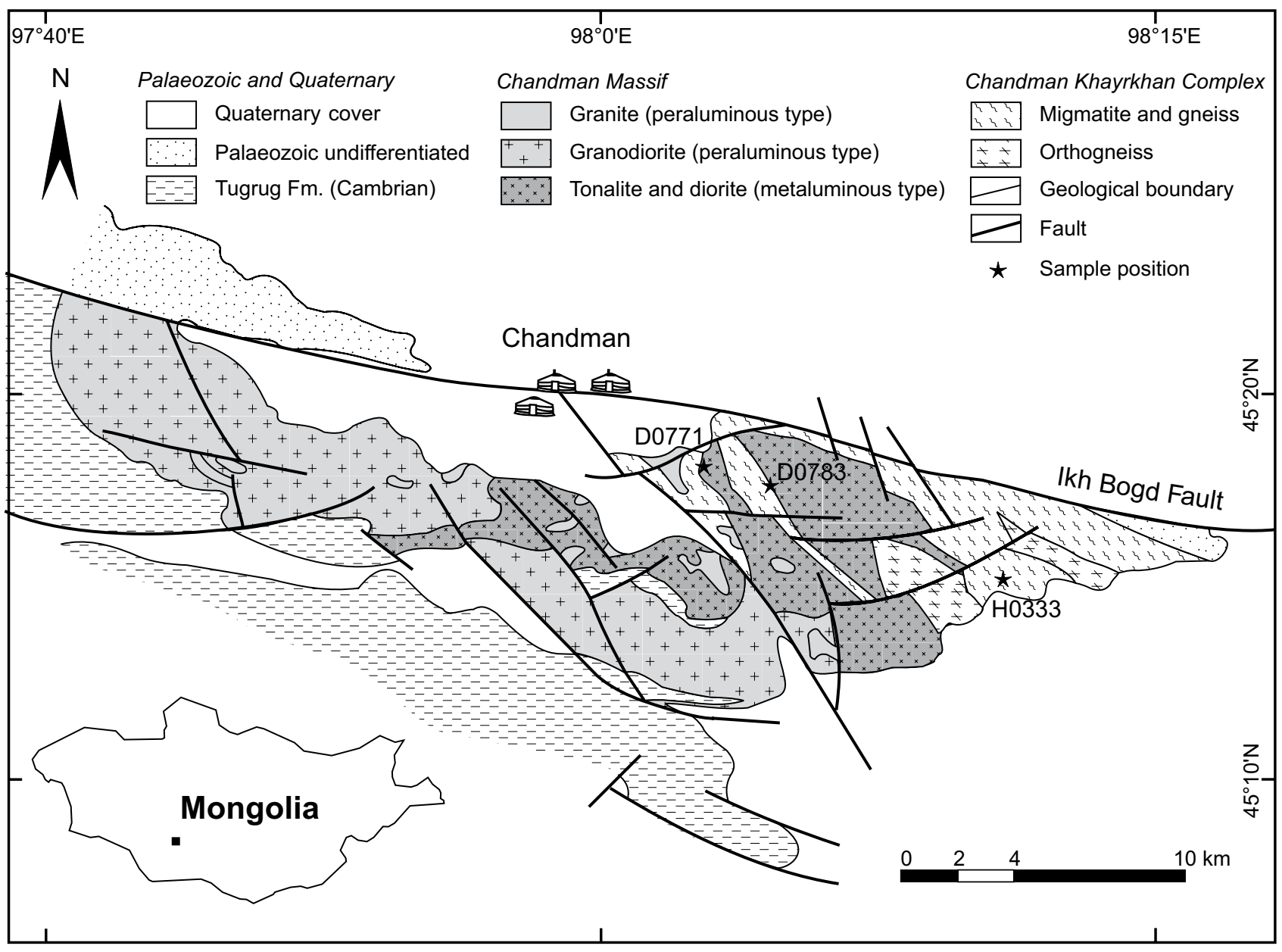

Fig. 1 Geological sketch map of the Chandman Massif area with the sample locations (after Hanžl and Aichler eds 2007).

\subsection{Metamorphic units which host the Chandman Massif}

The Chandman Khayrkhan Crystalline Complex (Fig. 1) consists of migmatites (stromatites, agmatites and diatexites), orthogneisses, gneisses and amphibolites with skarn lenses. The NWN-ESE trending foliation is moderately to steeply dipping to the south. The monotonous mineral composition of these rocks and their overprint by a HT-LP metamorphic event related to the intrusion of the Chandman Massif granitoids hamper the P-T calculations (Hrdličková et al. 2008) and reconstruction of metamorphic evolution of the unit. The mineral assemblages $\mathrm{Pl}+\mathrm{Kfs}+\mathrm{Bt} \pm \mathrm{Ms} \pm \mathrm{Grt} \pm$ Sill (migmatite) and $\mathrm{Amp}+\mathrm{Pl} \pm \mathrm{Bt} \pm \mathrm{Cpx} \pm \mathrm{Kfs}$ (amphibolite) correspond to upper amphibolite-facies $\left(\mathrm{M}_{1}\right)$. The second metamorphic event $\left(\mathrm{M}_{2}\right)$, which locally reached upper amphibolitefacies conditions, represents thermal effects of the Chandman Massif intrusion (Economos et al. 2008). Subsequently, the rocks have been strongly affected by a younger retrograde metamorphic event under the greenschist facies $\left(\mathrm{M}_{3}\right)$.
The Tugrug Formation is formed of siliceous, greengray chlorite-sericite schists with layers of light gray quartzites. Layers of tholeiitic metabasalts and tuffaceous sandstones are minor. The primary sedimentary and volcanic rocks metamorphosed under green-schist facies conditions evolved into biotite gneiss and amphibolite towards boundaries with the granodiorites of the Chandman Massif. The enclaves of slightly migmatized biotite to muscovite-biotite gneiss and amphibolite in the northern part of the Chandman Massif can be interpreted as equivalents of the Tugrug Formation.

\subsection{Igneous rocks of the Chandman Massif}

Intrusive age of the Chandman Massif was thought to be Ordovician according to Rauzer et al. (1987) but radiometric $\mathrm{U}-\mathrm{Pb}$ zircon dating of the Chandman diorite gave the Early Carboniferous age of $344.9 \pm 1.9 \mathrm{Ma}$ (Hrdličková et al. 2008). Contact between the Chandman Khayrkhan Crystalline Complex and the Chandman Massif is fuzzy. Metamorphic rocks along the contact show widespread effects of migmatization. Rocks of 
the Chandman Massif are intensively mylonitized along the deformation zone related to the Ikh Bogd Fault. The southern intrusive contact with the Cambrian Tugrug Formation is obscured by a number of faults.
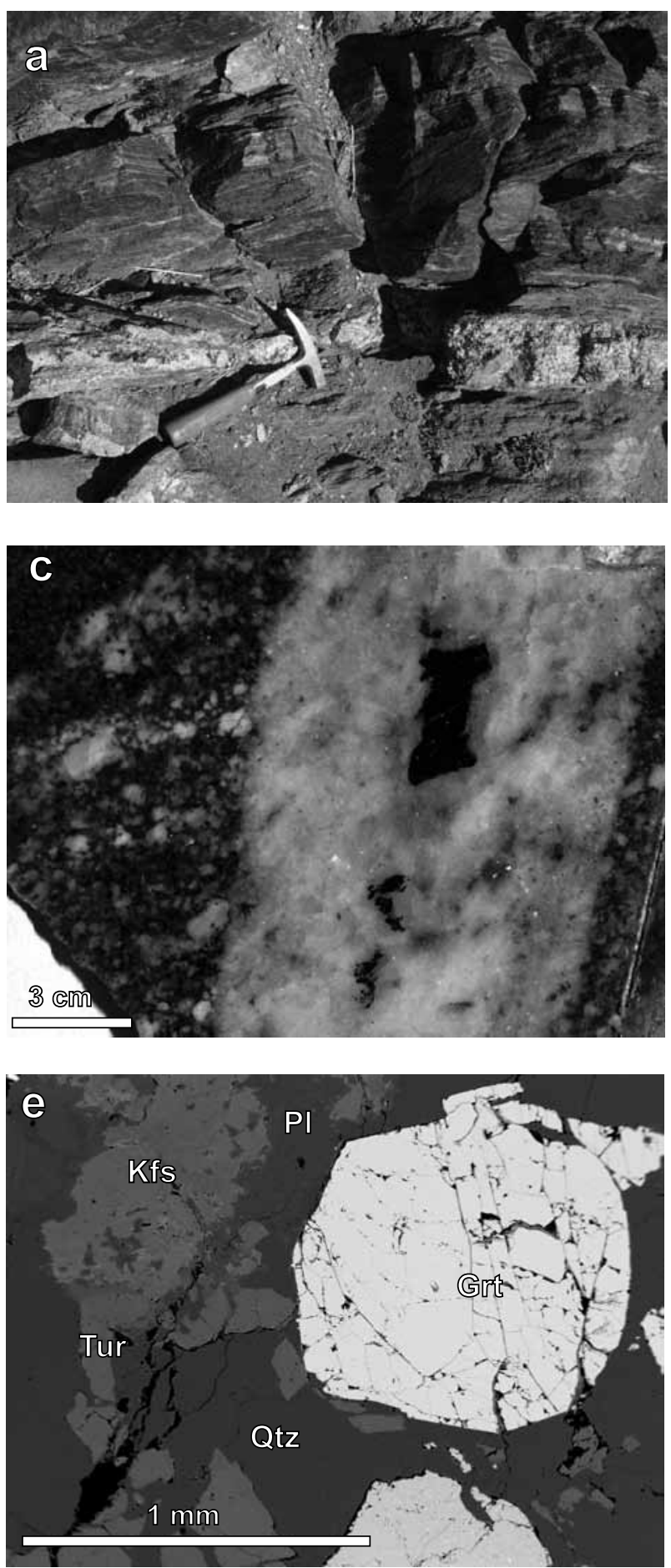

Granitoid rocks of the Chandman Massif (Fig. 1) can be divided, based on geochemical signatures, into two main groups (Economos et al. 2008): (1) metaluminous group represented by granodiorites and tonalites and
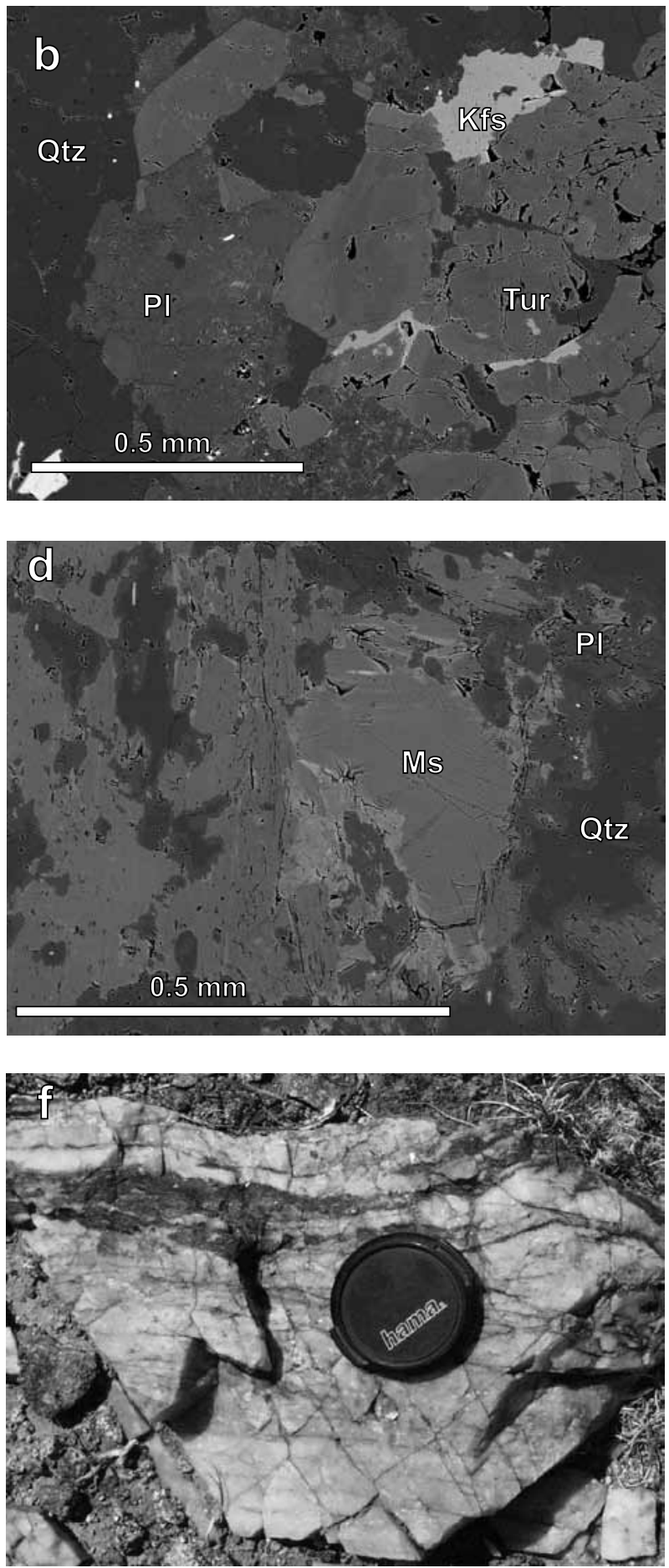

Fig. 2 Field photographs (a, c, f) and photomicrographs (b, d, e). a - A tourmaline-bearing pegmatite dyke in the migmatite of the Chandman Khayrkhan Crystalline Complex (sample H0333); b - Tourmaline partially replacing K-feldspar and plagioclase (sample D0783); c - Pegmatite dykes with tourmaline in tonalite of the Chandman Massif (sample D0771); d - Compositional zoning in muscovite from a pegmatite (sample D0771, BSE image); $\mathbf{e}$ - Garnet and tourmaline in the pegmatite (sample D0771, BSE image), $\mathbf{f}$ - Quartz veins with tourmaline in tonalite of the Chandman Massif (sample D0771B). 
(2) peraluminous group with prevailing granodiorites and rather sporadic granites. The rocks of both groups are calc-alkaline, medium-K for the metaluminous group and high-K (Peccerillo and Taylor 1976) for the peraluminous group.

The metaluminous group consists of biotite to biotite-amphibole granodiorite and tonalite situated mainly in the NE part of the massif (Fig. 1). Medium-grained, locally porphyritic granitoids contain varying proportions of biotite and hornblende. Small bodies of amphiboleand biotite-bearing diorite to gabbro and mafic enclaves are locally abundant in granodiorites. The metaluminous group shows the I-type mineralogical and geochemical signature. The pressures of 3-4 kbar and temperatures of $725-775^{\circ} \mathrm{C}$ reached during emplacement of the metaluminous granitoids were estimated by combination of the feldspar thermometric and hornblende barometric calculations (Economos et al. 2008).

Rocks of the peraluminous group can be subdivided into porphyritic biotite granodiorite and biotite (leuco-) granite. According to the geochemical data, the peraluminous group was derived from a crustal protolith (Economos et al. 2008). Porphyritic biotite granodiorite with biotite-rich schlieren forms the SW part of the massif. Fine- to medium-grained mafic enclaves are often migmatized and consist of biotite, plagioclase and quartz; locally amphibole and/or garnet are also present. The biotite granite to leucogranite forms several small bodies or dykes, from to 1 to $10 \mathrm{~m}$ thick, intruded into the granodiorites to tonalities of the Chandman Massif and metamorphic rocks of the Chandman Khayrkhan Crystalline Complex. The granites are light grey, locally pink and commonly medium-grained. They consist mainly of perthitic alkali feldspar, plagioclase, quartz, muscovite and biotite, often as a subordinate phase only. Apatite, ilmenite, garnet and zircon are present as accessory minerals. The peraluminous rocks of the Chandman Massif do not contain tourmaline.

\subsection{Pegmatite dykes and quartz veins}

Tourmaline-bearing pegmatite dykes and quartz veins are spatially related to the metaluminous rocks of the Chandman Massif. The pegmatite dykes reaching the thickness up to first tens of centimetres and length up to first tens of metres with mineral assemblage $\mathrm{Qtz}+\mathrm{Pl}+\mathrm{Kfs} \pm \mathrm{Bt} \pm \mathrm{Ms}$ are widespread in whole Chandman Massif. However tourmaline-bearing pegmatite dykes and quartz-tourmaline veins are spatially related to the metaluminous rocks of the Chandman Massif and occur exclusively near the contact with the surrounding migmatites.

Dykes of pegmatite grading to aplite are also present in migmatites of the Chandman Khayrkhan Crystalline Complex. Several centimetres to decimetres thick dykes have a modal composition similar to the migmatite leucosome assemblage, except for tourmaline that is occasionally present. The dykes are usually parallel with NWN-ESE trending foliation in the metamorphic rocks, moderately to steeply dipping to the south. However, there were also found small veins located in the shear zones, perpendicular to the orientation of leucosome layers in the stromatitic migmatites (Fig. 2a).

\section{Methodology}

Chemical analyses of minerals were obtained using a Cameca SX-100 electron microprobe at the Joint Laboratory of the Department of Geological Sciences, Faculty of Science, Masaryk University in Brno and the Czech Geological Survey, Brno. The measurements were carried out in a wave-dispersion mode under the following conditions: acceleration voltage $-15 \mathrm{kV}$, beam diameter of $5 \mu \mathrm{m}$ and probe current of $30 \mathrm{nA}$. The integration time was $20 \mathrm{~s}$ and the standards employed $\left(\mathrm{K}_{\alpha}\right.$ lines): augite $(\mathrm{Si}, \mathrm{Mg})$, orthoclase $(\mathrm{K})$, jadeite $(\mathrm{Na})$, chromite $(\mathrm{Cr})$, almandine (Al), andradite (Fe, $\mathrm{Ca})$, rhodonite $(\mathrm{Mn})$ and $\mathrm{TiO}_{2}$ (Ti). The formulae of feldspars were recalculated assuming 8 oxygen atoms per formula unit (apfu) and those of micas to $22 \mathrm{O}$ apfu. Formulae of tourmalines were obtained on the basis of $31(\mathrm{O}, \mathrm{OH}, \mathrm{F})$, assuming $\mathrm{OH}+\mathrm{F}=4$ apfu and $\mathrm{B}=3$ apfu. Abbreviations of mineral names are after Kretz (1983).

\section{Paragenetic attributes of tourmaline- -bearing dykes and host rocks}

The majority of migmatized gneisses of the Chandman Khayrkhan Crystalline Complex is tourmaline-free. The mineral is a very rare accessory component in some melanosome layers in the biotite- and sillimanite-rich migmatites. The small dykes of granite grading to pegmatite, containing tourmaline, are situated exclusively in the eastern part the Chandman Khayrkhan Crystalline Complex, near the contact with the Chandman Massif. On the other hand, tourmaline is relatively common in the pegmatite dykes and aplite and quartz veins crosscutting the metaluminous I-type granitoids of the Chandman Massif near the contact with migmatites.

\subsection{Host rocks of the tourmaline-bearing pegmatite dykes and quartz-tourmaline veins}

The migmatites consist mainly of quartz, plagioclase, biotite, muscovite, sillimanite, and their structure varies from stromatite to diatexite. Plagioclase from melano- 
some $\left(\mathrm{An}_{35-40}\right)$ is characterized by higher Ca contents than that in pegmatite $\left(\mathrm{An}_{26-27}\right)$. On the other hand, biotite in the host migmatite melanosome and in the tourmalinebearing pegmatite is chemically well comparable, having $\mathrm{Fe} /(\mathrm{Fe}+\mathrm{Mg})=0.40-0.42,{ }^{\mathrm{IV}} \mathrm{Al}=2.53-2.58$ apfu and $\mathrm{Ti}$ $=0.17-0.20 \mathrm{apfu}$ (Tab. 1). Rare aggregates of needle-like sillimanite are usually enclosed in biotite.

The orthogneisses (pearl gneisses) are dark grey medium-grained rocks consisting of plagioclase, quartz, biotite, muscovite, zircon and apatite. Deformed oligo- clase $\left(\mathrm{An}_{28-29}\right)$ porphyroblasts reach up to $1 \mathrm{~mm}$ in size. Biotite characterizes $\mathrm{Fe} /(\mathrm{Fe}+\mathrm{Mg})=0.51-0.52,{ }^{\mathrm{IV}} \mathrm{Al}=$ 2.46-2.48 apfu and $\mathrm{Ti}=0.32-0.33 \mathrm{apfu}$, whereas muscovite contains ${ }^{\mathrm{IV}} \mathrm{Al}=1.72-1.75 \mathrm{apfu}$. Both of the micas forming small aggregates wrapping around plagioclase grains are chemically homogeneous.

Biotite tonalites are medium-grained, porphyritic, slightly deformed rocks, locally with biotite-rich enclaves. Plagioclase phenocrysts are usually normally zoned $\left(\mathrm{An}_{20-31}\right)$. Quartz occurs as anhedral grains with

Tab. 1 Representative chemical compositions of micas (structural formulae on the basis of $22 \mathrm{O}$ )

\begin{tabular}{|c|c|c|c|c|c|c|c|c|c|}
\hline \multirow[b]{2}{*}{ Group } & \multicolumn{6}{|c|}{ pegmatite and aplite } & \multicolumn{3}{|c|}{ host rocks } \\
\hline & Type Ia & Type Ia & Type Ib & Type Ib & Type II & Type II & Type Ib & Type Ib & Type II \\
\hline Locality & H0333a & H0333a & D0783 & D0783 & D0771 & D0771 & D0783 & D0771 & D0771 \\
\hline Mineral & $\mathrm{Bt}$ & Ms & $\mathrm{Bt}$ & Ms & Ms & Ms & $\mathrm{Ms}$ & $\mathrm{Bt}$ & $\mathrm{Bt}$ \\
\hline $\mathrm{SiO}_{2}$ & 37.26 & 44.84 & 35.82 & 45.79 & 46.33 & 46.59 & 45.88 & 36.06 & 36.81 \\
\hline $\mathrm{TiO}_{2}$ & 1.99 & 2.03 & 1.62 & 0.70 & 0.06 & 0.14 & 0.71 & 2.75 & 1.66 \\
\hline $\mathrm{Al}_{2} \mathrm{O}_{3}$ & 17.48 & 29.62 & 16.83 & 32.38 & 32.87 & 31.71 & 31.04 & 16.44 & 16.63 \\
\hline $\mathrm{Cr}_{2} \mathrm{O}_{3}$ & 0.07 & 0.00 & 0.00 & 0.00 & 0.00 & 0.00 & 0.00 & 0.00 & 0.00 \\
\hline $\mathrm{FeO}$ & 16.33 & 4.53 & 20.15 & 3.66 & 3.00 & 4.06 & 4.53 & 19.49 & 16.69 \\
\hline $\mathrm{MnO}$ & 0.22 & 0.00 & 0.51 & 0.07 & 0.02 & 0.03 & 0.00 & 0.52 & 0.26 \\
\hline $\mathrm{MgO}$ & 13.07 & 1.34 & 10.45 & 0.95 & 0.93 & 1.25 & 1.25 & 10.31 & 13.17 \\
\hline $\mathrm{CaO}$ & 0.00 & 0.01 & 0.07 & 0.00 & 0.00 & 0.00 & 0.00 & 0.00 & 0.01 \\
\hline $\mathrm{Na}_{2} \mathrm{O}$ & 0.24 & 0.32 & 0.08 & 0.38 & 0.42 & 0.49 & 0.28 & 0.07 & 0.07 \\
\hline $\mathrm{K}_{2} \mathrm{O}$ & 9.10 & 10.60 & 9.42 & 10.64 & 10.97 & 10.62 & 10.81 & 9.71 & 9.52 \\
\hline $\mathrm{BaO}$ & 0.17 & 0.76 & 0.10 & 0.27 & 0.03 & 0.11 & 0.29 & 0.15 & 0.30 \\
\hline $\mathrm{Rb}_{2} \mathrm{O}$ & 0.00 & 0.00 & 0.00 & 0.01 & 0.00 & 0.00 & 0.03 & 0.03 & 0.00 \\
\hline $\mathrm{ZnO}$ & 0.00 & 0.00 & 0.02 & 0.02 & 0.00 & 0.04 & 0.01 & 0.03 & 0.13 \\
\hline $\mathrm{F}$ & 0.01 & 0.05 & 0.00 & 0.00 & 0.08 & 0.04 & 0.00 & 0.00 & 0.00 \\
\hline $\mathrm{Cl}$ & 0.03 & 0.00 & 0.03 & 0.00 & 0.00 & 0.00 & 0.01 & 0.02 & 0.02 \\
\hline $\mathrm{H}_{2} \mathrm{O}^{*}$ & 4.02 & 4.29 & 3.89 & 4.41 & 4.38 & 4.40 & 4.38 & 3.91 & 3.96 \\
\hline $\mathrm{O}=\mathrm{F}, \mathrm{Cl}$ & 0.01 & 0.02 & 0.01 & 0.00 & 0.03 & 0.02 & 0.00 & 0.01 & 0.01 \\
\hline Total & 99.97 & 98.39 & 98.97 & 99.27 & 99.06 & 99.46 & 99.21 & 99.49 & 99.22 \\
\hline \multicolumn{10}{|l|}{ (apfu) } \\
\hline$\overline{\mathrm{Si}}$ & 5.541 & 6.232 & 5.515 & 6.230 & 6.285 & 6.325 & 6.283 & 5.517 & 5.559 \\
\hline${ }^{\mathrm{IV}} \mathrm{Al}$ & 2.459 & 1.768 & 2.485 & 1.770 & 1.715 & 1.675 & 1.717 & 2.483 & 2.441 \\
\hline${ }^{\mathrm{V}} \mathrm{Al}$ & 0.606 & 3.085 & 0.569 & 3.423 & 3.540 & 3.399 & 3.293 & 0.482 & 0.518 \\
\hline $\mathrm{Ti}$ & 0.222 & 0.213 & 0.187 & 0.072 & 0.006 & 0.014 & 0.073 & 0.317 & 0.189 \\
\hline $\mathrm{Cr}$ & 0.008 & 0.000 & 0.000 & 0.000 & 0.000 & 0.000 & 0.000 & 0.000 & 0.000 \\
\hline $\mathrm{Fe}$ & 2.031 & 0.527 & 2.594 & 0.416 & 0.340 & 0.460 & 0.519 & 2.494 & 2.108 \\
\hline $\mathrm{Mn}$ & 0.027 & 0.000 & 0.066 & 0.008 & 0.002 & 0.003 & 0.000 & 0.067 & 0.033 \\
\hline $\mathrm{Mg}$ & 2.899 & 0.278 & 2.399 & 0.192 & 0.189 & 0.253 & 0.255 & 2.351 & 2.964 \\
\hline $\mathrm{Zn}$ & 0.000 & 0.000 & 0.002 & 0.002 & 0.000 & 0.004 & 0.001 & 0.004 & 0.014 \\
\hline $\mathrm{Ca}$ & 0.000 & 0.001 & 0.011 & 0.000 & 0.000 & 0.000 & 0.000 & 0.000 & 0.002 \\
\hline $\mathrm{Na}$ & 0.068 & 0.086 & 0.024 & 0.099 & 0.110 & 0.129 & 0.073 & 0.022 & 0.020 \\
\hline $\mathrm{K}$ & 1.727 & 1.879 & 1.849 & 1.847 & 1.899 & 1.840 & 1.889 & 1.894 & 1.834 \\
\hline $\mathrm{Ba}$ & 0.010 & 0.041 & 0.006 & 0.014 & 0.001 & 0.006 & 0.016 & 0.009 & 0.018 \\
\hline $\mathrm{Rb}$ & 0.000 & 0.000 & 0.000 & 0.001 & 0.000 & 0.000 & 0.003 & 0.003 & 0.000 \\
\hline $\mathrm{OH}^{*}$ & 3.989 & 3.978 & 3.993 & 4.000 & 3.966 & 3.982 & 3.998 & 3.994 & 3.994 \\
\hline $\mathrm{F}$ & 0.003 & 0.022 & 0.000 & 0.000 & 0.034 & 0.018 & 0.000 & 0.000 & 0.000 \\
\hline $\mathrm{Cl}$ & 0.008 & 0.000 & 0.007 & 0.000 & 0.000 & 0.000 & 0.002 & 0.006 & 0.006 \\
\hline Total & 19.598 & 18.110 & 19.708 & 18.075 & 18.087 & 18.108 & 18.121 & 19.643 & 19.700 \\
\hline
\end{tabular}

* calculated from stoichiometry 
undulatory extinction. Biotite with $\mathrm{Fe} /(\mathrm{Fe}+\mathrm{Mg})=$ $0.41-0.42,{ }^{\text {IV }} \mathrm{Al}=2.44-2.45$ apfu and $\mathrm{Ti}=0.19-0.21 \mathrm{apfu}$ occurs as fine-grained aggregates or individual grains often concentrated around plagioclase. Apatite, magnetite and ilmenite are typical accessory minerals.

\subsection{Pegmatite dykes related to metamorphic rocks}

Two samples of pegmatite have been studied. The sample H0333 (for localization see Fig. 1) was taken from approximately $10 \mathrm{~cm}$ thick pegmatite dyke in the migmatized gneisses, whereas the sample D0783 comes from a pegmatite dyke cutting an orthogneiss body in the northern part the Chandman Crystalline Complex.

The pegmatite dykes represent an equigranular, medium- to coarse-grained rock containing subhedral quartz (43-45 vol. \%), plagioclase (53-54 vol. \%) and tourmaline ( 2 vol. \%), with minor K-feldspar, muscovite and biotite (up to 2 vol. \% each).

Plagioclase forms subhedral to euhedral tabular crystals with normal zoning $\left(\mathrm{An}_{19-27}\right)$ and $\mathrm{SrO}$ contents of $\sim 0.1$ wt. $\%$ (Tab. 2). The cores of plagioclase crystals are commonly sericitized, especially in those bordering tourmaline. Anhedral to subhedral grains of K-feldspar $\left(\mathrm{Or}_{95-99} \mathrm{Ab}_{5-9}\right)$ with relatively high content of $\mathrm{BaO}=$ 0.7-1.4 wt. \% (Fig. 3a) enclose small inclusions of plagioclase and quartz. Younger subhedral K-feldspar $\left(\mathrm{Or}_{99}\right.$ $A b_{1}$ ), with negligible $\mathrm{Ba}$ content, forms small grains at plagioclase-quartz contacts. Partially chloritized flakes of biotite randomly distributed in the rock are characterized by $\mathrm{Fe} /(\mathrm{Fe}+\mathrm{Mg})=0.41-0.52,{ }^{\mathrm{IV}} \mathrm{Al}=2.46-2.55$ apfu and $\mathrm{Ti}=0.19-0.22 \mathrm{apfu}$, whereas the primary muscovite by $\mathrm{Fe} /(\mathrm{Fe}+\mathrm{Mg})=0.61-0.69$ and ${ }^{\mathrm{IV}} \mathrm{Al}=1.64-1.77$ apfu (Fig. $3 b)$. Muscovite is rare and usually occurs close to tourmaline. Fluorapatite, xenotime, allanite and monazite are relatively common. Ilmenite laths, containing 7-11 mol. $\%$ of the pyrophanite component, are locally replaced by hematite and Ti-rich magnetite.

Tourmaline of the sample H0333 forms columnar crystals, up to $1 \mathrm{~cm}$ long, oriented perpendicularly to the boundary between melanosome and pegmatite and oval tourmaline-quartz graphic intergrowths up to $3 \mathrm{~cm}$ in diameter in the central parts of the dykes. Tourmaline D0783 occurs as small accumulations of subhedral crystals sporadically distributed in the host pegmatite, sometimes replacing K-feldspar and plagioclase (Fig. 2b). Tourmaline grains, up to $0.3 \mathrm{~mm}$ in diameter, contain small inclusions of quartz and $\mathrm{K}$-feldspar.

Tab. 2 Representative chemical compositions of feldspars (structural formulae on the basis of $8 \mathrm{O}$ )

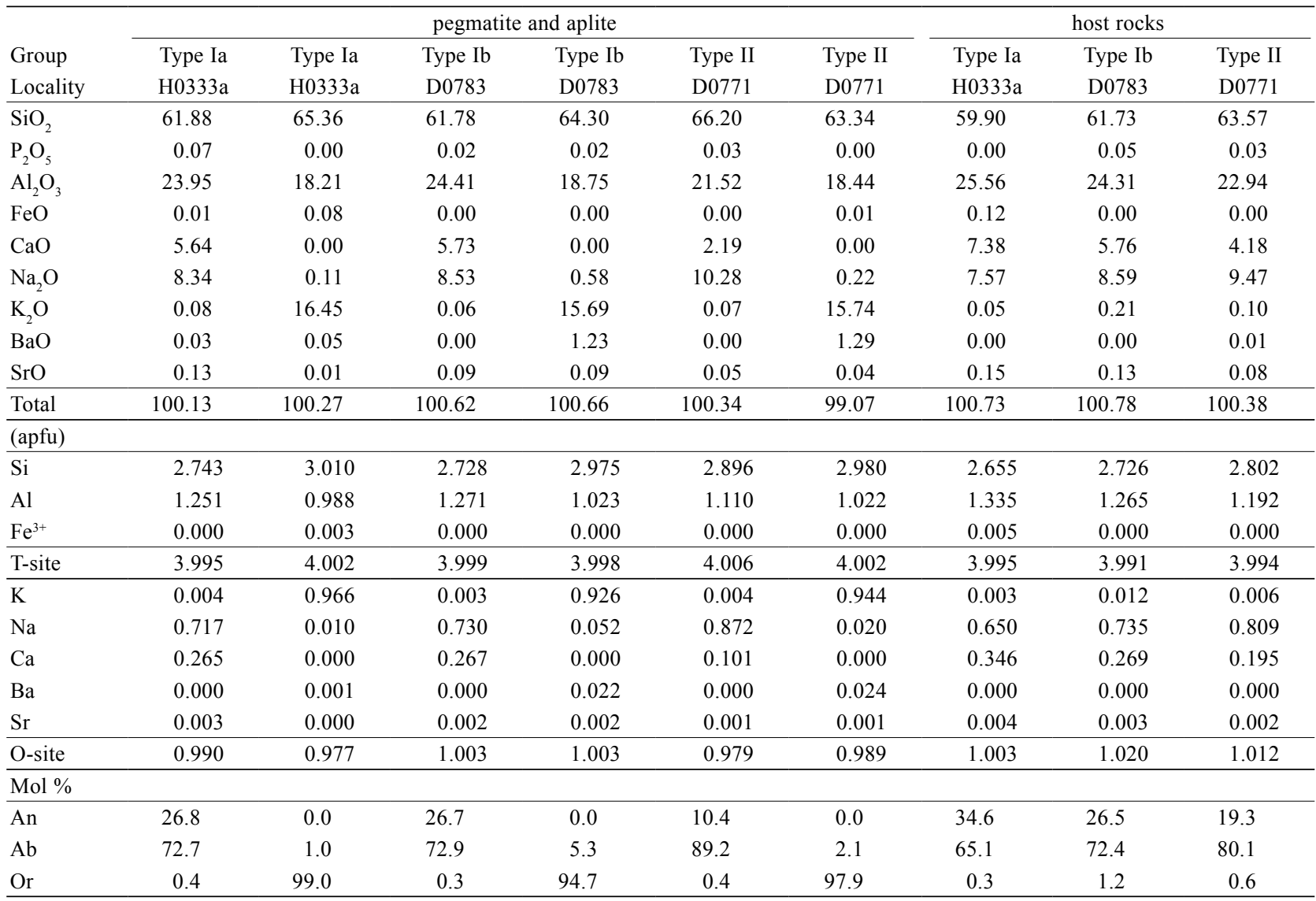




\subsection{Pegmatite dykes related to metalumi- nous granitoids}

Pegmatite dykes with tourmaline cutting biotite-rich tonalite of the Chandman Massif (Fig. 2c) crop out on the flat mountain ridge southeast of the Chandman village (Fig. 1). They reach first tens of metres in length and up to first decimetres in thickness.

The studied pegmatite dyke D0771 is only about 8 $\mathrm{cm}$ thick, with visible zoning formed by a granite-like to aplitic marginal part and a central "graphic core", consisting of quartz and K-feldspar intergrowths. The core contains also tourmaline, garnet, ilmenite, allanite, magnetite, monazite and apatite, whereas the marginal parts consist of plagioclase (48 vol. \%), anhedral quartz (46 vol. \%), muscovite (4 vol. \%), garnet (1.7 vol. \%), and $\mathrm{K}$-feldspar (0.3 vol. \%).

Subhedral plagioclase with normal zoning $\left(\mathrm{An}_{9-11}\right)$ is slightly sericitized and contains frequent inclusions of small anhedral K-feldspar crystals $\left(\mathrm{Or}_{98-97} \mathrm{Ab}_{2-3}\right)$ with
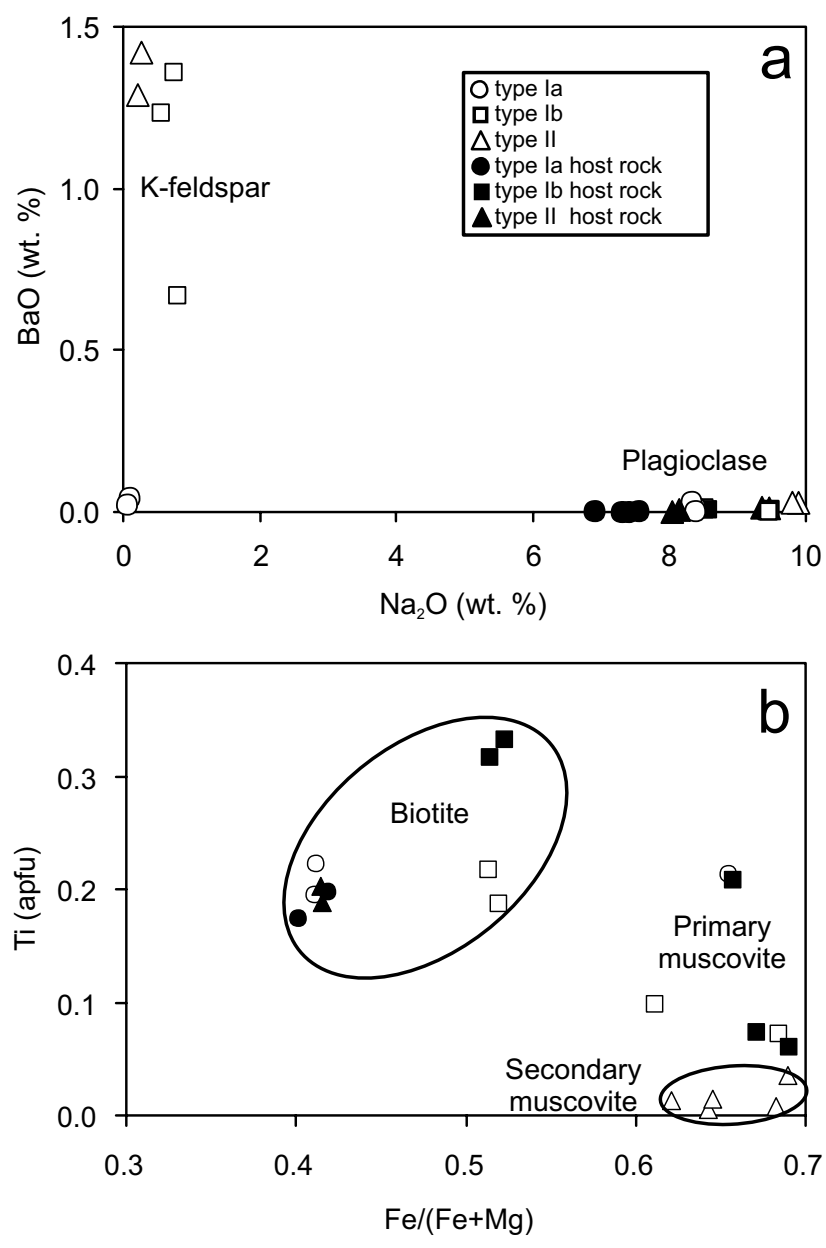

Fig. 3a $\mathrm{Na}_{2} \mathrm{O}$ vs. $\mathrm{BaO}$ diagram for the feldspar from pegmatites and their host rocks; $\mathbf{b}-\mathrm{Fe} /(\mathrm{Fe}+\mathrm{Mg})$ vs. Ti diagram for the micas from pegmatites and their host rocks. a $\mathrm{BaO}$ content reaching $1.3-1.4$ wt. \% (Tab. 2). White micas (Fig. 3b), containing 0.03-2.34 wt. \% $\mathrm{BaO}$, represent a solid-solution of ganterite and muscovite. Small flakes of the mica are usually homogeneous with ${ }^{\mathrm{IV}} \mathrm{Al}$ varying from 1.68 to 1.72 apfu and $F$ from 0.02 to 0.03 apfu. However, in some places the homogeneous core in muscovite flakes is rimed by a Ba-rich zone, $0.01-0.03$ $\mathrm{mm}$ thick, with ${ }^{\mathrm{IV}} \mathrm{Al}=1.75-1.85$ apfu and $\mathrm{F}=0.02-0.03$ apfu. The Ba-rich white mica can be also surrounded by a plagioclase rims up to $0.1 \mathrm{~mm}$ thick (Fig. 2d). The garnet crystals $\left(\mathrm{Sps}_{63-66} \mathrm{Alm}_{26-28} \operatorname{Prp}_{6-5} \mathrm{Adr}_{3}\right)$ reach up to 1-2 $\mathrm{mm}$ in diameter (Fig. 2e). Tourmaline usually forms subhedral crystals, up to $2 \mathrm{~cm}$ in diameter, situated in the central part of dykes. Ilmenite contains $c$. $11 \mathrm{~mol}$. \% of the pyrophanite component.

\subsection{Quartz veins related to metaluminous I-type granitoids}

Quartz-tourmaline veins (sample D0771B) are often spatially associated with the pegmatite dykes and they reach thicknesses varying from 1 to $20 \mathrm{~cm}$. In the veins, hair-like aggregates and needle crystals of tourmaline form stripes, up to $2 \mathrm{~mm}$ thick (Fig. 2f), enclosed in the medium- to finely granular mosaic composed of anhedral grains of quartz. Tourmaline is rarely associated with euhedral apatite crystals up to $0.2 \mathrm{~mm}$ in size.

\section{Tourmaline composition}

Three types of tourmaline were distinguished based on geological position and paragenetic assemblage in the tourmaline-bearing veins (Fig. 2):

I. Tourmaline bound to pegmatites in the migmatites and orthogneisses,

II. Tourmaline of pegmatite dykes cutting the metaluminous igneous rocks,

III. Tourmaline of quartz veins cutting the metaluminous rocks.

Tourmaline I (Fig. 4) is represented by Fe-rich dravite $(\mathrm{Al}=5.74-6.43 \mathrm{apfu}, \mathrm{Fe} /(\mathrm{Fe}+\mathrm{Mg})=0.41-0.48) . \mathrm{A}$ relatively homogeneous core with the smooth zoning is rimed by a Fe-rich oscillatory-zoned tourmaline (up to $0.1 \mathrm{~mm}$ thick rim). The main substitution trend related to the increase of $\mathrm{Na}$ and $\mathrm{Mg}+\mathrm{Fe}^{2+}$ and decrease of $\mathrm{Al}$ and the $\mathrm{X}$-site vacancy corresponds well to the exchange vector ${ }^{\mathrm{X}} \mathrm{Na}_{1}{ }^{\mathrm{Y}} \mathrm{R}^{2+}{ }_{1}{ }^{\mathrm{X}}{ }_{-1}{ }^{\mathrm{Y}} \mathrm{Al}$ (Fig. 5a-f). The elevated $\mathrm{Ca}$ content in the rim (up to $0.24 \mathrm{Ca}$ apfu) can be related to the minor uvite-type substitution ${ }^{\mathrm{x}} \mathrm{Ca}_{1}{ }^{\mathrm{Z}} \mathrm{R}^{2+}{ }_{1}{ }^{\mathrm{X}} \mathrm{Na}_{-1}{ }^{\mathrm{Z}} \mathrm{Al}{ }_{-1}$.

Tourmaline II (Fig. 4) has a transitional schorl-dravite composition $(\mathrm{Al}=5.78-6.10 \mathrm{apfu}, \mathrm{Fe} /(\mathrm{Fe}+\mathrm{Mg})=0.36$ $0.62)$, and it is richer in $\mathrm{Na}$ than the tourmaline $\mathrm{I}(\mathrm{Na}=$ $0.62-0.79 \mathrm{apfu}, \mathrm{Ca}=0.06-0.16 \mathrm{apfu})$. Its crystals consist 


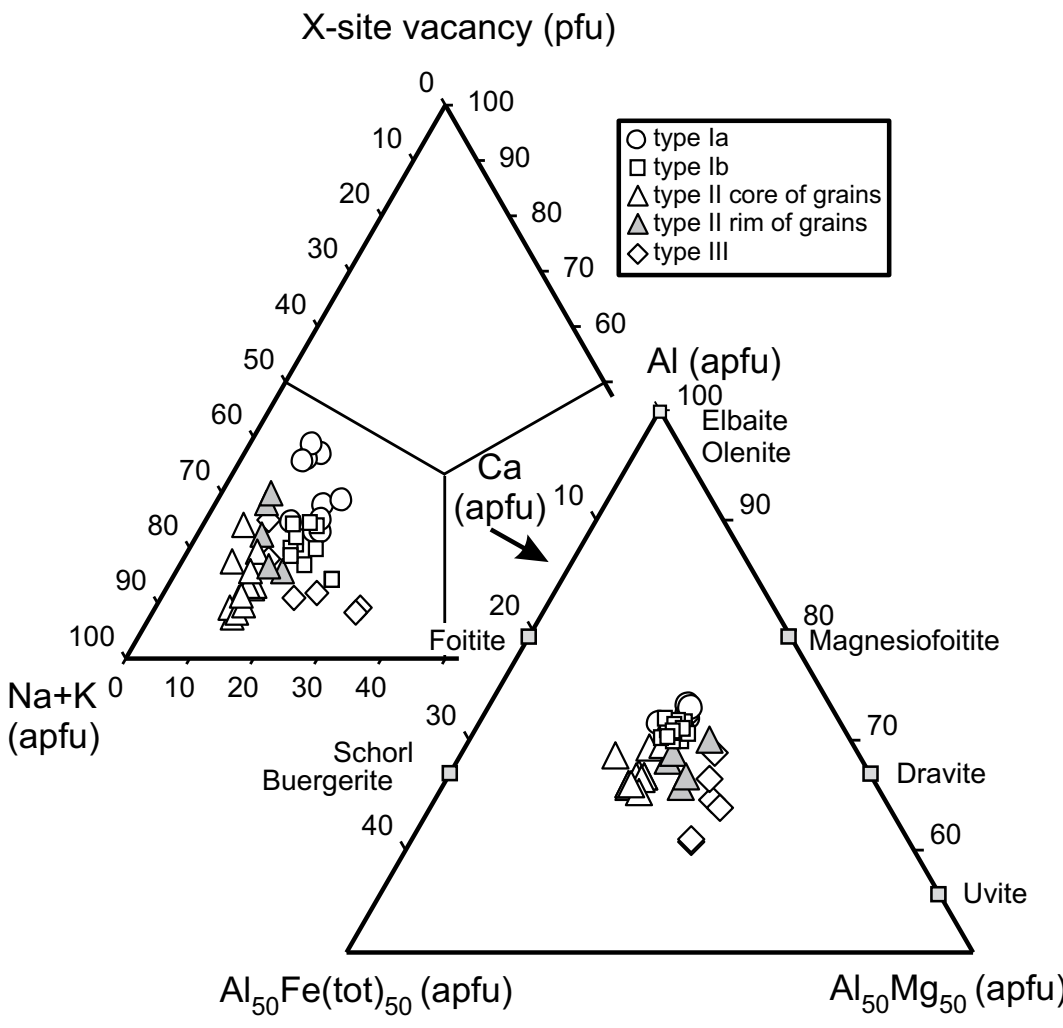

Fig. $4 \mathrm{Al}_{50} \mathrm{Fe}$ (tot) $)_{50}-\mathrm{Al}_{50} \mathrm{Mg}_{50}-\mathrm{Al}$ and $\mathrm{Na}+\mathrm{K}-\mathrm{Ca}-\mathrm{X}-$ site vacancy ternary plots for tourmaline from the Chandman Massif and the Chandman Khayrkhan Crystalline Complex. of two significantly different zones: a sector-zoned core with $\mathrm{Fe} /(\mathrm{Fe}+\mathrm{Mg})=0.36-0.62$ and a homogeneous $\mathrm{Fe}$ rich dravite rim with $\mathrm{Fe} /(\mathrm{Fe}+\mathrm{Mg})=0.44-0.45$. Decrease in the $\mathrm{Na}$ content and relatively constant $\mathrm{Al}$ in the tourmaline core can be related to the substitution ${ }^{\mathrm{X}} \square_{1}{ }^{\mathrm{W}}(\mathrm{OH})_{1}$ ${ }^{\mathrm{x}} \mathrm{Na}_{-1}{ }^{\mathrm{W}} \mathrm{O}_{-1}$ coupled to the minor substitution of $\mathrm{Fe}$ for $\mathrm{Mg}$. On the other hand, some parts of the tourmaline grains evolved towards more $\mathrm{Mg}$-rich and $\mathrm{Al}$-deficient compositions with a dominant substitution of ${ }^{\mathrm{X}} \mathrm{Na}_{1}{ }^{\mathrm{Y}} \mathrm{R}^{2+}{ }_{1}$ $\mathrm{x}_{\square}{ }_{-1}^{\mathrm{Y}} \mathrm{Al}_{-1}$ (Fig. 5a-b, d).

Thin needles of the tourmaline III represent irregularly oscillatory zoned dravite to Ca-rich dravite, with $\mathrm{Fe} /(\mathrm{Fe}+\mathrm{Mg})=0.36-0.44$ and $\mathrm{Al}=5.23-6.04$ apfu (Fig. $5 \mathrm{a}-\mathrm{d})$. The decrease in $\mathrm{Al}$ and $\mathrm{Na}(\mathrm{Na}=0.58-0.60 \mathrm{apfu})$ coupled with increase in the $\mathrm{Ca}$ content $(0.10-0.32 \mathrm{Ca}$ apfu) can be linked to the substitution ${ }^{\mathrm{x}} \mathrm{Ca}_{1}{ }^{\mathrm{Z}} \mathrm{R}^{2+}{ }_{1} \mathrm{x}_{\mathrm{Na}}$ ${ }^{\mathrm{z}} \mathrm{Al}_{-1}$ (Fig. 5a-b, d), often accompanied by a minor replacement ${ }^{\mathrm{X}_{\square}}{ }_{1}{ }^{\mathrm{Y}} \mathrm{Al}_{1}{ }^{\mathrm{X}_{\mathrm{Na}}} \mathrm{Na}_{-1}{ }^{\mathrm{Y}} \mathrm{R}^{2+}{ }_{-1}$.

\section{Discussion}

The tourmaline-bearing pegmatites and quartz veins are spatially related to the contact aureole of the metaluminous rocks of the Chandman Massif. The main characteristics of this magmatic-hydrothermal system are summarized as follows.

Pegmatite dykes crosscut migmatites and igneous rocks close to intrusive contacts of the Chandman Massif.
Pegmatite melt with boron should have solidus temperatures lower than that of the common tonalitic melts. For that reason probably the tourmaline-bearing pegmatites fill tiny fractures in the igneous rocks near their contact with migmatites.

Chemical compositions of rock-forming minerals in the pegmatite dykes are different (by their high $\mathrm{Ca}$ content) from typical tourmaline-bearing pegmatites and granites (London 1999; Buriánek and Novák 2007; Neiva et al. 2008).

Geological relationships indicate that the quartztourmaline veins follow a final stage of the pegmatite evolution.

\subsection{Source of pegmatite melts}

Granitic pegmatites in general are characterized by fractional crystallization of the main rock-forming minerals (e.g. plagioclase, K-feldspar and biotite) during evolution of the large granitic bodies. The contents of the anorthite component in plagioclase and $\mathrm{Ba}$ contents in $\mathrm{K}$-feldspar decrease from parental granite to aplite and pegmatite (Neiva et al. 2008). High contents of $\mathrm{Ca}$ in plagioclase and tourmaline are not typical of pegmatite generated by fractionation of granitic melts. All studied biotites from the pegmatite show $\mathrm{Fe} /(\mathrm{Fe}+\mathrm{Mg})$ ratios comparable with their host rocks (Fig. 3b). On the other hand, the Ti content in biotite from orthogneiss is significantly 

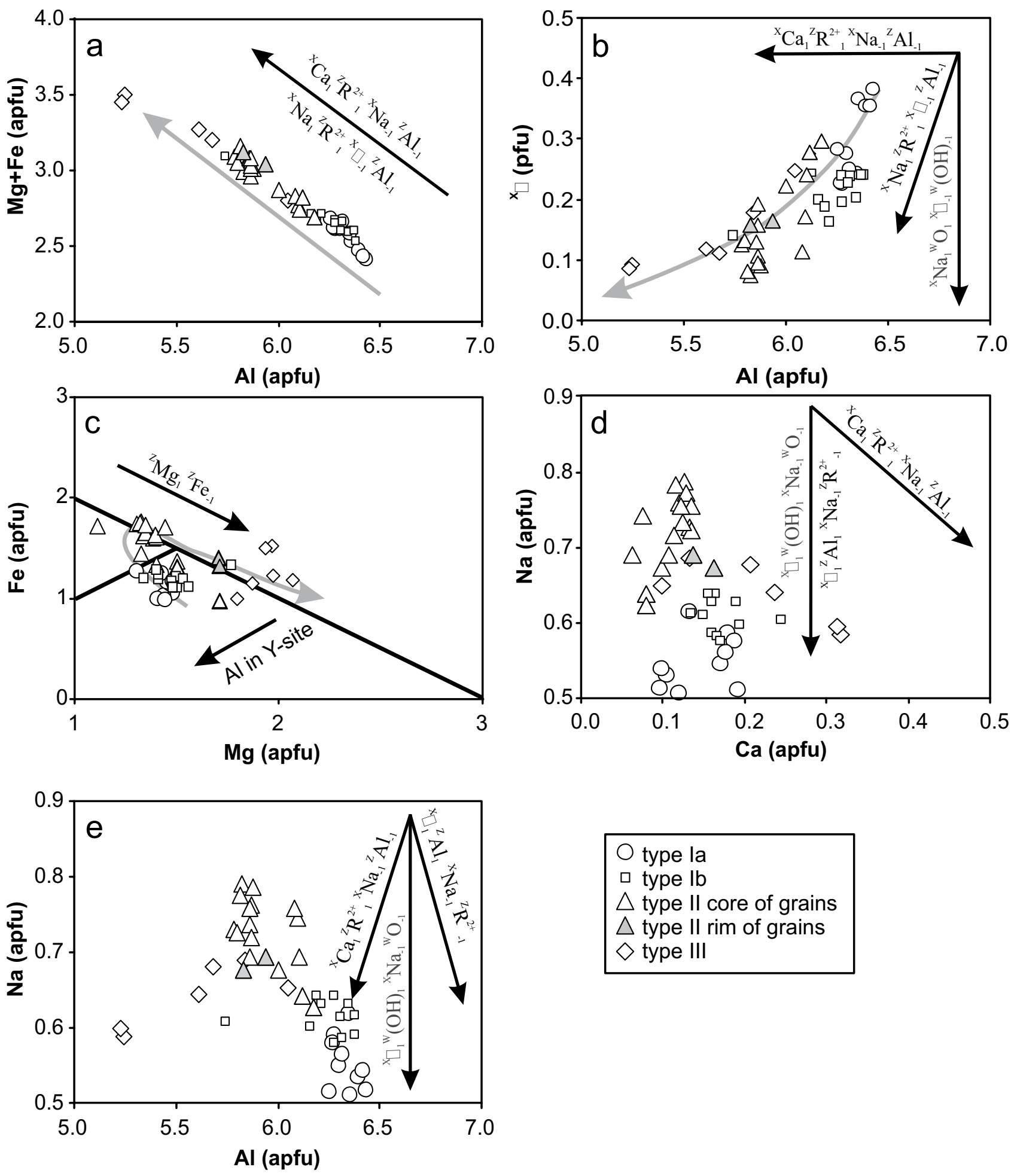

$\bigcirc$ type la
$\square$ type Ib
$\triangle$ type II core of grains
$\triangle$ type II rim of grains
$\diamond$ type III

Fig. 5 Composition of tourmaline from granites. $\mathbf{a}-\mathrm{Mg}+\mathrm{Fe}$ vs. $\mathrm{Al} ; \mathbf{b}-{ }^{\mathrm{x}} \square$ vs. $\mathrm{Al} ; \mathbf{c}-\mathrm{Fe}$ vs. $\mathrm{Mg}$ (grey arrow shows evolution of tourmaline from pegmatite hosted by migmatite to quartz veins); $\mathbf{d}-\mathrm{Na}$ vs. $\mathrm{Ca} ; \mathbf{e}-\mathrm{Na}$ vs. Al.

higher (0.33-0.32 apfu) than in the pegmatites. Chemical composition of associated tourmaline and biotite in the pegmatite dykes occurring in migmatites are comparable with tourmaline and biotite in the metapelites metamor- phosed under upper amphibolite-facies conditions (Henry and Guidotti 1985; Henry et al. 2005).

During emplacement of the granitoids of the Chandman Massif (at 3-4 kbar and $725-775^{\circ} \mathrm{C}$; Economos 
Tab. 3 Representative chemical compositions of tourmaline from pegmatites and quartz-tourmaline veins [structural formulae on the basis of 31 $(\mathrm{O}, \mathrm{OH}, \mathrm{F})]$

\begin{tabular}{|c|c|c|c|c|c|c|c|c|c|c|c|c|}
\hline Group & Type Ia & Type Ia & Type Ia & Type II & Type II & Type II & Type II & Type II & Type II & Type III & Type III & Type III \\
\hline Locality & H0333a & $\mathrm{H} 0333 \mathrm{a}$ & H0333a & D0771 & D0771 & D0771 & D0771 & D0771 & D0771 & D0771B & D0771B & D0771B \\
\hline $\mathrm{SiO}_{2}$ & 36.84 & 35.80 & 35.60 & 35.87 & 35.46 & 36.03 & 36.25 & 36.32 & 36.16 & 36.26 & 36.24 & 37.24 \\
\hline $\mathrm{TiO}_{2}$ & 0.27 & 0.68 & 0.56 & 0.84 & 0.93 & 0.44 & 0.39 & 0.32 & 0.28 & 1.34 & 1.58 & 0.18 \\
\hline $\mathrm{Al}_{2} \mathrm{O}_{3}$ & 33.11 & 32.73 & 32.39 & 29.76 & 29.15 & 31.10 & 31.39 & 29.82 & 30.37 & 26.50 & 26.58 & 30.34 \\
\hline $\mathrm{V}_{2} \mathrm{O}_{3}$ & 0.00 & 0.00 & 0.00 & 0.00 & 0.04 & 0.00 & 0.00 & 0.07 & 0.04 & 0.05 & 0.03 & 0.10 \\
\hline $\mathrm{Cr}_{2} \mathrm{O}_{3}$ & 0.02 & 0.00 & 0.00 & 0.00 & 0.00 & 0.00 & 0.02 & 0.00 & 0.00 & 0.00 & 0.00 & 0.00 \\
\hline $\mathrm{FeO}$ & 7.71 & 9.24 & 8.49 & 11.56 & 12.50 & 10.36 & 9.49 & 10.12 & 9.54 & 10.84 & 10.74 & 8.42 \\
\hline $\mathrm{MgO}$ & 6.10 & 5.32 & 6.00 & 5.36 & 5.29 & 5.34 & 6.10 & 6.91 & 6.92 & 7.86 & 7.79 & 7.69 \\
\hline $\mathrm{CaO}$ & 0.68 & 0.75 & 1.00 & 0.67 & 0.74 & 0.42 & 0.44 & 0.91 & 0.77 & 1.76 & 1.75 & 0.76 \\
\hline $\mathrm{MnO}$ & 0.03 & 0.06 & 0.05 & 0.26 & 0.27 & 0.31 & 0.13 & 0.03 & 0.06 & 0.02 & 0.68 & 0.04 \\
\hline $\mathrm{ZnO}$ & 0.00 & 0.00 & 0.00 & 0.01 & 0.08 & 0.03 & 0.00 & 0.04 & 0.01 & 0.00 & 0.02 & 0.09 \\
\hline $\mathrm{Na}_{2} \mathrm{O}$ & 1.61 & 1.93 & 1.75 & 2.34 & 2.23 & 2.30 & 1.99 & 2.09 & 2.15 & 1.79 & 1.84 & 2.17 \\
\hline $\mathrm{K}_{2} \mathrm{O}$ & 0.04 & 0.05 & 0.06 & 0.07 & 0.07 & 0.05 & 0.02 & 0.04 & 0.04 & 0.04 & 0.03 & 0.02 \\
\hline $\mathrm{F}$ & 0.00 & 0.00 & 0.00 & 0.00 & 0.00 & 0.00 & 0.00 & 0.00 & 0.00 & 0.02 & 0.14 & 0.00 \\
\hline $\mathrm{H}_{2} \mathrm{O}^{*}$ & 3.68 & 3.64 & 3.63 & 3.59 & 3.56 & 3.61 & 3.63 & 3.62 & 3.62 & 3.56 & 3.53 & 3.67 \\
\hline $\mathrm{B}_{2} \mathrm{O}_{3} *$ & 10.68 & 10.56 & 10.51 & 10.39 & 10.32 & 10.45 & 10.51 & 10.48 & 10.48 & 10.35 & 10.41 & 10.64 \\
\hline $\mathrm{O}=\mathrm{F}$ & 0.00 & 0.00 & 0.00 & 0.00 & 0.00 & 0.00 & 0.00 & 0.00 & 0.00 & 0.01 & 0.06 & 0.00 \\
\hline Total & 100.77 & 100.75 & 100.04 & 100.72 & 100.65 & 100.44 & 100.35 & 100.76 & 100.43 & 100.39 & 101.29 & 101.36 \\
\hline \multicolumn{13}{|l|}{ (apfu) } \\
\hline \multicolumn{13}{|l|}{ T site } \\
\hline $\mathrm{Si}^{4+}$ & 5.996 & 5.891 & 5.885 & 5.998 & 5.970 & 5.991 & 5.995 & 6.023 & 5.996 & 6.089 & 6.051 & 6.081 \\
\hline $\mathrm{Al}^{3+}$ & 0.004 & 0.109 & 0.115 & 0.002 & 0.030 & 0.009 & 0.005 & 0.000 & 0.004 & 0.000 & 0.000 & 0.000 \\
\hline \multicolumn{13}{|l|}{$Z$ site } \\
\hline $\mathrm{Al}^{3+}$ & 6.000 & 6.000 & 6.000 & 5.863 & 5.754 & 6.000 & 6.000 & 5.826 & 5.930 & 5.245 & 5.230 & 5.839 \\
\hline $\mathrm{Mg}^{2+}$ & 0.000 & 0.000 & 0.000 & 0.137 & 0.246 & 0.000 & 0.000 & 0.174 & 0.070 & 0.755 & 0.770 & 0.161 \\
\hline \multicolumn{13}{|l|}{ Y site } \\
\hline $\mathrm{Ti}^{4+}$ & 0.032 & 0.085 & 0.069 & 0.105 & 0.118 & 0.056 & 0.048 & 0.040 & 0.035 & 0.169 & 0.199 & 0.023 \\
\hline $\mathrm{Al}^{3+}$ & 0.348 & 0.238 & 0.196 & 0.000 & 0.000 & 0.087 & 0.113 & 0.000 & 0.000 & 0.000 & 0.000 & 0.000 \\
\hline $\mathrm{Cr}^{3+}$ & 0.003 & 0.000 & 0.000 & 0.000 & 0.000 & 0.000 & 0.002 & 0.000 & 0.000 & 0.000 & 0.000 & 0.000 \\
\hline $\mathrm{V}^{3+}$ & 0.000 & 0.000 & 0.000 & 0.000 & 0.006 & 0.000 & 0.000 & 0.009 & 0.005 & 0.007 & 0.004 & 0.012 \\
\hline $\mathrm{Fe}^{2+}$ & 1.049 & 1.271 & 1.174 & 1.617 & 1.760 & 1.441 & 1.313 & 1.403 & 1.323 & 1.522 & 1.500 & 1.150 \\
\hline $\mathrm{Mg}^{2+}$ & 1.481 & 1.304 & 1.479 & 1.199 & 1.081 & 1.324 & 1.503 & 1.535 & 1.641 & 1.213 & 1.168 & 1.711 \\
\hline $\mathrm{Mn}^{2+}$ & 0.004 & 0.008 & 0.007 & 0.036 & 0.039 & 0.043 & 0.018 & 0.004 & 0.009 & 0.003 & 0.097 & 0.006 \\
\hline $\mathrm{Zn}^{2+}$ & 0.000 & 0.000 & 0.000 & 0.001 & 0.010 & 0.004 & 0.000 & 0.005 & 0.001 & 0.000 & 0.002 & 0.011 \\
\hline \multicolumn{13}{|l|}{$\mathrm{X}$ site } \\
\hline $\mathrm{Ca}^{2+}$ & 0.118 & 0.133 & 0.177 & 0.119 & 0.133 & 0.075 & 0.078 & 0.161 & 0.137 & 0.316 & 0.312 & 0.132 \\
\hline $\mathrm{Na}^{+}$ & 0.507 & 0.614 & 0.561 & 0.759 & 0.728 & 0.742 & 0.639 & 0.672 & 0.690 & 0.584 & 0.596 & 0.686 \\
\hline $\mathrm{K}^{+}$ & 0.009 & 0.011 & 0.013 & 0.015 & 0.014 & 0.010 & 0.005 & 0.008 & 0.008 & 0.008 & 0.007 & 0.003 \\
\hline Vacancy & 0.365 & 0.242 & 0.249 & 0.107 & 0.126 & 0.172 & 0.277 & 0.159 & 0.165 & 0.092 & 0.085 & 0.179 \\
\hline$\overline{\mathrm{OH}}$ & 4.000 & 4.000 & 4.000 & 4.000 & 4.000 & 4.000 & 4.000 & 4.000 & 4.000 & 3.992 & 3.929 & 4.000 \\
\hline $\mathrm{F}^{-}$ & 0.000 & 0.000 & 0.000 & 0.000 & 0.000 & 0.000 & 0.000 & 0.000 & 0.000 & 0.008 & 0.071 & 0.000 \\
\hline $\mathrm{B}^{3+}$ & 3.000 & 3.000 & 3.000 & 3.000 & 3.000 & 3.000 & 3.000 & 3.000 & 3.000 & 3.000 & 3.000 & 3.000 \\
\hline
\end{tabular}

* calculated from stoichiometry, total Fe as FeO

et al. 2008), the roof pendants were partially melted under conditions higher then the tourmaline-out isograd $\left(\sim 670^{\circ} \mathrm{C}\right.$ for $\left.5 \mathrm{kbar}\right)$ defined by Kawakami (2001). The pegmatite dykes in the contact aureole of the Chandman Massif, both occurring in the adjacent metamorphic rocks as well as in tonalite, have similar modal composition $(\mathrm{Qtz}+\mathrm{Pl}+\mathrm{Kfs}+\mathrm{Tur} \pm \mathrm{Bt} \pm \mathrm{Ms})$. The high $\mathrm{Ca}$ content in plagioclase and tourmaline, high content of $\mathrm{Ba}$ in $\mathrm{K}$-feldspar as well as sporadic presence of K-feldspar indicates an unusual origin of the parental pegmatite-forming melt. According to Inger and Harris (1993), the contents of Ba, $\mathrm{Ca}$, and $\mathrm{K}$ in the anatectic melt are strongly influenced by the presence of water during partial melting reactions consuming biotite and feldspars. With increasing $\mathrm{H}_{2} \mathrm{O}$ content at constant $\mathrm{P}-\mathrm{T}$ conditions the amounts of alkali feldspar crystallized from the melt decreases (Holtz and Johannes 1991; Patiño Douce and Harris 1998). The presence of water-rich fluids during anatexis enables production of a melt depleted in $\mathrm{K}$ and enriched in $\mathrm{Ca}$, $\mathrm{Fe}, \mathrm{Na}$ and $\mathrm{Ba}$ (Conrad et al. 1988; Holtz and Johannes 1991). The presence of $\mathrm{H}_{2} \mathrm{O}$ and boron reduce the solidus temperature and viscosities of granitic melts (e.g. Baker and Vaillancourt 1995), and the boron-bearing melt may be segregated due to its lower viscosity. 
Tourmaline pegmatites in the migmatites in the Chandman Crystalline Complex can be interpreted as a product of segregation and crystallization of hydrous melts derived by melting of metapelites in the contact aureole of the Chandman Massif. Subsequently, small amounts of such a presumably mobile, boron-bearing melt could have migrated from the migmatites to fractures propagated in the nearby cooling metaluminous igneous rocks. This process may have been accompanied by fractional crystallization of the primitive anatectic melts together with tourmalines II and III.

\subsection{Evolution of the pegmatite-forming melts}

In typical granitic systems, the tourmaline is Ca-poor and evolves from schorl-dravite toward olenite-foitite solid solution (London 1999; Novák et al 2004; Buriánek and Novák 2007). For example, tourmaline from granites in the Moldanubicum (Bohemian Massif, Czech Republic) are characterized by low $\mathrm{Ca}$ contents $(\leq 0.17 \mathrm{apfu})$ and fractionation trends of magmatic tourmalines showing an increase in $\mathrm{Al}, \mathrm{Fe} /(\mathrm{Fe}+\mathrm{Mg}), \mathrm{F}$, and $\mathrm{Na}$ or degree of vacancy in the $\mathrm{X}$-site. This suggests substitutions of the following types as the dominant exchange vectors (Buriánek and Novák 2007): foitite type $\left({ }^{\mathrm{X}} \square_{1}{ }^{\mathrm{Y}} \mathrm{Al}_{1}{ }^{\mathrm{X}} \mathrm{Na}_{-1}\right.$ $\left.{ }^{\mathrm{Y}} \mathrm{R}^{2+}{ }_{-1}\right)$, the oxy-foitite type $\left({ }^{\mathrm{x}} \square{ }_{1}{ }^{\mathrm{Y}} \mathrm{Al}_{2}{ }^{\mathrm{W}} \mathrm{O}_{1}{ }^{\mathrm{x}} \mathrm{Na}_{-1} \mathrm{Y}^{\mathrm{Y}} \mathrm{R}^{2+}{ }_{-2}^{-1}\right.$ $\left.{ }^{\mathrm{w}}(\mathrm{OH})_{-1}\right)$ and the $\mathrm{X}$-site vacant olenite type $\left({ }^{\mathrm{X}} \square_{1}{ }^{\mathrm{r}} \mathrm{Al}_{3}{ }^{\mathrm{W}} \mathrm{O}_{2}\right.$ $\left.{ }^{\mathrm{x}} \mathrm{Na}_{-1}{ }^{\mathrm{Y}} \mathrm{R}^{2+}{ }_{-3}^{\mathrm{w}}(\mathrm{OH})_{-2}\right)$. On the other hand, trends of the studied tourmalines crystallizing from the melt stage to hydrothermal conditions show a decrease in $\mathrm{Al}$ and increase in $(\mathrm{Fe}+\mathrm{Mg})$ together with decreasing vacancy in the X-site (Fig. 5a-d). At the same time, high calcium contents (0.06-0.32 apfu) are typical of all the tourmaline types. Dominant substitutions in the pegmatites are $\mathrm{x}_{\square}{ }_{1}{ }^{\mathrm{W}}(\mathrm{OH})_{1}{ }^{\mathrm{X}} \mathrm{Na}_{-1}{ }^{\mathrm{W}} \mathrm{O}_{-1}$ and ${ }^{\mathrm{X}} \mathrm{Na}_{1}{ }^{\mathrm{Y}} \mathrm{R}^{2+}{ }_{1} \mathrm{x}_{\square}{ }_{-1}{ }^{\mathrm{Y}} \mathrm{Al} \mathrm{l}_{-1}$, however, in the hydrothermal veins substantial $\mathrm{Ca}$ would be a result of the substitution ${ }^{\mathrm{x}} \mathrm{Ca}_{1}{ }^{\mathrm{Z}} \mathrm{R}^{2+}{ }_{1} \mathrm{Xaa}_{-1}{ }^{\mathrm{Z}} \mathrm{Al}{ }_{-1}$.

Geological position at the boundary of the Chandman Massif is compatible with the view that pegmatite dykes in the migmatites and in the metaluminous igneous rocks represent products of crystallization from a similar melt. Differences in compositions of tourmaline and plagioclase from individual dykes can be interpreted as a result of the melt fractionation. The pegmatite dykes filling tiny fractures in the metaluminous igneous rocks of the Chandman Massif are characterized by lower contents of $\mathrm{Ca}$ in plagioclase $\left(\mathrm{An}_{9-11}\right)$ compared to the pegmatite in the contact aureole $\left(\mathrm{An}_{19-29}\right)$. Tourmaline I (Fe-rich dravite) occurring in the pegmatite from the contact aureole is characterized by higher total $\mathrm{Al}$ (Fig. 4) and lower $\mathrm{Na}$ (>0.5 apfu, Fig. 5f) compared to the tourmaline II (schorl-dravite) in the pegmatite from the Chandman Massif itself. Tourmaline II is associated with spessartine-almandine-rich, chemically homogeneous, euhedral garnet grains. These compositional features are similar to those reported for typical magmatic garnet crystallizing below $700^{\circ} \mathrm{C}$ in granitic melt (Clarke 1981; Manning 1983; Bray 1988).

White mica is frequently present in the pegmatite occurring in the metaluminous igneous rocks of the Chandman Massif. The lower Ti content (0.01-0.04 apfu) indicates a secondary origin of the micas (Miller et al. 1981). In contrast, muscovite from pegmatite in the contact aureole (Fig. 3b) can by classified as being of a primary origin (Miller et al. 1981). Under subsolidus conditions, $\mathrm{Ba}$ is easily mobile in the hydrothermal fluids (Harris et al. 2003) and a high content of Ba in rims of the white mica is a good evidence for the K-feldspar breakdown. The secondary white mica (Fig. 2d) in the pegmatite can be interpreted as a product of reaction between K-feldspar and post-magmatic hydrothermal fluids introduced during the subsolidus pegmatite evolution.

At the final stage of the pegmatite melt evolution, the extraction of aqueous fluids produced quartz veins with a small portion of tourmaline. The chemical composition of the tourmaline, especially the high contents of $\mathrm{Ca}$ and $\mathrm{Mg}$, can be interpreted as a consequence of the interaction of boron-rich fluids with surroundings rocks (Gawęda et al. 2002; Dini et al. 2008) or mixing of postmagmatic fluids from different fluid sources (Buriánek and Novák 2004; Dini et al. 2008). A slightly higher fluorine content $(\mathrm{F}<0.14 \mathrm{apfu})$ in comparison to other studied tourmalines $(\mathrm{F}<0.01 \mathrm{apfu})$ is characteristic of the fluids extracted from the peraluminous melt (London 1997; Thomas et al. 2000).

\section{Conclusions}

Tourmalines from pegmatites and quartz veins in the contact aureole of the Chandman Massif exhibit chemical compositions (mainly elevated $\mathrm{Ca}$ and $\mathrm{Mg}$ contents) different from typical granitic pegmatites and tourmaline granites worldwide. The following exchange vectors characterize the main substitutions in tourmaline of the studied rocks: ${ }^{\mathrm{x}} \square_{1}{ }^{\mathrm{W}}(\mathrm{OH})_{1}{ }^{\mathrm{x}} \mathrm{Na}_{-1}{ }^{\mathrm{W}} \mathrm{O}_{-1},{ }^{\mathrm{x}} \mathrm{Na}_{1}{ }^{\mathrm{Z}} \mathrm{R}^{2+}{ }_{1}{ }^{\mathrm{x}} \square_{-1}{ }^{\mathrm{Z}} \mathrm{Al} l_{-1}$ and ${ }^{\mathrm{X}} \mathrm{Ca}_{1}{ }_{1}^{\mathrm{Z}} \mathrm{R}^{2+}{ }_{1} \mathrm{X}^{\mathrm{X}}{ }_{-1}{ }^{\mathrm{Z}} \mathrm{Al}{ }_{-1}$.

Generation and segregation of boron-bearing melt from the metasediments in the contact aureole of the Chandman Massif led to the formation of tourmalinebearing pegmatite dykes spatially distributed along the contact of the metaluminous igneous rocks and migmatites. Variation of chemical compositions of schorldravite in terms of the $\mathrm{Al}, \mathrm{F}, \mathrm{Na}, \mathrm{Fe}$ and $\mathrm{Mg}$ contents is interpreted as a result of the parental anatectic melt fractionation. The quartz-tourmaline veins are explained as a product of crystallization of fluids exsolved from the 
pegmatite melt. Chemical compositions of hydrothermal tourmaline reflect mixing of the boron-rich fluids extracted from the pegmatite with an $\mathrm{Mg}-\mathrm{Ca}$-rich external component represented by biotite-rich metaluminous igneous host rocks.

Acknowledgements. The authors wish to thank P. Uher and anonymous reviewer for a critical review of the manuscript. Last but not least, the careful editorial handling by M. Novák helped us to improve the readability of the text. The field-work was done during the project 'Geological Survey of the Mongolian Altay on the Scale $1: 50000$ ' undertaken in the frame of the Program of the Development Assistance Project of the Czech Republic. The work was supported by the Czech Science Foundation (GAČR), Grant No. 205/05/P223 to DB.

\section{References}

Badarch G, Cunningham WD, Windley BF (2002) A new terrane subdivision for Mongolia: implications for the Phanerozoic crustal growth of central Asia. J Asian Earth Sci 20: 87-100

Baker DR, Vaillancourt J (1995) The low viscosities of $\mathrm{F}$ and $\mathrm{H}_{2} \mathrm{O}$ bearing granitic melts and implications for melt extraction and transport. Earth Planet Sci Lett 132: 199-211

BRAY EA (1988) Garnet compositions and their use as indicators of peraluminous granitoid petrogenesis southeastern Arabian Shield. Contrib Mineral Petrol 100: 205-212

Buriánek D, NovÁk M (2004) Morphological and compositional evolution of tourmaline from nodular granite at Lavičky near Velké Meziříčí, Moldanubicum, Czech Republic. J Czech Geol Soc 49: 81-90

BuriáneK D, NovÁK M (2007) Compositional evolution and substitutions in disseminated and nodular tourmaline from leucocratic granites: examples from the Bohemian Massif, Czech Republic. Lithos 95: 148-164

Clarke DB (1981) The mineralogy of peraluminous granites: a review. Canad Miner 19: 3-17

ConRad WK, Nicholls IA, Wall VJ (1988) Water saturated, and undersaturated melting of metaluminous, and peraluminous crustal compositions at $10 \mathrm{~kb}$ : evidence for the origin of silicic magmas in the Taupo volcanic zone, New Zealand, and other occurrences. J Petrol 29: 765-803

Dingwell DB, Knoche R, Webb SL, Pichavant M (1992) The effect of $\mathrm{B}_{2} \mathrm{O}_{3}$ on the viscosity of haplogranitic liquids. Amer Miner 77: 457-461

Dini A, Mazzarini F, Musumeci G, Rocchi S (2008) Multiple hydro-fracturing by boron-rich fluids in the Late Miocene contact aureole of eastern Elba Island (Tuscany, Italy). Terra Nova 20: 318-326
Economos RC, Hanžl P, HrdličKová K, Buriánek D, SAid L-O, Gerdes A, Paterson SR (2008) Geochemical and structural constraints on the magmatic history of the Chandman Massif of the eastern Mongolian Altay Range, SW Mongolia. J Geosci 53: 335-352

Finger F, Clemens J D (1995) Migmatitization and "secondary" granitic magmas: effects of emplacement and crystallization of "primary" granitoids in Southern Bohemia, Austria. Contrib Mineral Petrol 120: 311-326

Gawęda A, PieczKa A, KraczKa J (2002) Tourmalines from the Western Tatra Mountains (W-Carpathians, S-Poland): their characteristics and petrogenetic importance. Eur J Mineral 14: 943-955

HANŽL P, Aichler J (eds) (2007) Geological Survey of the Mongolian Altay at a scale 1: 50000 (Zamtyn Nuruu - 50), Final report of the International Development Cooperation project of the Czech Republic. Czech Geological Survey, Brno \& MRPAM, Ulaanbaatar, pp $1-376$

Harris N, McMillan A, Holness M, Uken RON, Watkeys M, Rogers N, FALlick A (2003) Melt generation and fluid flow in the thermal aureole of the Bushveld Complex. J Petrol 44: 1031-1054

HenRy DJ, GuidOTti CV (1985) Tourmaline as a petrogenetic indicator mineral: an example from the staurolite-grade metapelites of NW Maine. Amer Miner 70: 1-15

Henry DJ, Guidotti CV, Thomson JA (2005) The Ti-saturation surface for low-to-medium pressure metapelitic biotite: implications for geothermometry and Ti-substitution mechanisms. Amer Miner 90: 316-328

Holtz F, Johannes W (1991) Genesis of peraluminous granites I. Experimental investigation of melt composition at 3 and $5 \mathrm{~kb}$ and various $\mathrm{H}_{2} \mathrm{O}$ activities. J Petrol 32: 935-958

Hrdličková K, BolormaA K, Buriánek D, HanžL P, Gerdes A, JANOUŠEK V (2008) Petrology and age of metamorphosed rock in tectonic slices inside the Palaeozoic sediments of the eastern Mongolian Altay, SW Mongolia. J Geosci 53: 139-165

INGER S, HARRIS N (1993) Geochemical constraints on leucogranite magmatism in the Langtan Valley, Nepal Himalaya. J Petrol 34: 345-368

KAWAKAMI T (2001) Tourmaline breakdown in the migmatite zone of the Ryoke metamorphic belt, SW Japan. J Metamorph Geol 19: 61-75

KRETZ R (1983) Symbols for rock-forming minerals. Amer Miner 68: 277-279

LONDON D (1997) Estimating abundances of volatile and other mobile components in evolved silicic melts through mineral-melt equilibria. J Petrol 38: 1691-1706

LONDON D (1999) Stability of tourmaline in peraluminous granite systems; the boron cycle from anatexis to hydrothermal aureoles. Eur J Mineral 11: 253-262

London D, MANNIng DAC (1995) Chemical variation and 
significance of tourmaline from Southwest England. Econ Geol 90: 495-519

London D, Morgan GBV, Wolf MB (1996) Boron in granitic rocks and their contact aureoles. In: GREw ES, Anovitz LM (eds) Boron: Mineralogy, Petrology and Geochemistry. Mineralogical Society of America Reviews in Mineralogy 33: 299-330

MANNING DAC (1983) Chemical variation in garnets from aplites and pegmatites, peninsular Thailand. Mineral Mag 47: 353-358

Miller CF, Stoddard EF, Bradfish LJ, Dollase WA (1981) Composition of plutonic muscovite: genetic implications. Canad Mineral 19: 25-34

Montel JM, Marignac C, Barbey P, Pichavant M (1992) Thermobarometry and granite genesis: the Hercynian low-P high-T Velay anatectic dome (French Massif Central). J Metamorph Geol 10: 1-15

Neiva AMR, Gomes MEP, Ramos JMF, Silva PB (2008) Geochemistry of granitic aplite-pegmatite sills and their minerals from Arcozelo da Serra area (Gouveia, central Portugal). Eur J Mineral 20: 465-485

Novák M, Povondra P, Selway JB (2004) Schorl-oxyschorl to dravite-oxy-dravite tourmaline from granitic pegmatites; examples from the Moldanubicum, Czech Republic. Eur J Mineral 16: 323-333

Patiño Douce AE, Harris N (1998) Experimental constraints on Himalayan anatexis. J Petrol 39: 689-710
Pichavant M (1981) An experimental study of the effect of boron on a water saturated haplogranite at $1 \mathrm{kbar}$ vapour pressure. Contrib Mineral Petrol 76: 430-439

Rauzer AA, Zhanchiv DI, Golyakov VI, YhHina IF, Ivanov IG, Tsukernik AB, Afonin VV, Smirnov IG, Bykhover VI, Kravtsev AV, BaAtarkhuyag A, Skoryukin Mi, Khodikov IV, Mantsev NV, Okaemov SV, Mischin VA, ENKHSAJKHAN T (1987) Report on results of geological mapping on scale $1: 200,000$ in the south-western part of Mongolian Altay in 1983-1986, Mongolian National Republic. Tekhnoexport, Moscow, pp 1-352 (in Russian)

Peccerillo A, TAylor SR (1976) Geochemistry of Eocene calc-alkaline volcanic rocks from the Kastamonu area, Northern Turkey. Contrib Mineral Petrol 58: 63-81

SEngör AC, NATAL'In BA, Burtman VS (1993) Evolution of the Altaid tectonic collage and Paleozoic crustal growth in Eurasia. Nature 364: 299-306

Sperlich R, Giere R, Frey M (1996) Evolution of compositional polarity and zoning in tourmaline during prograde metamorphism of sedimentary rocks in the Swiss Central Alps. Amer Miner 81: 1222-1236

Thomas R, Webster JD, Heinrich W (2000) Melt inclusions in pegmatite quartz: complete miscibility between silicate melts and hydrous fluids at low pressure. Contrib Mineral Petrol 139: 394-401 